\title{
Investigating the relation between legal disclosure environments and IT governance transparency
}

\author{
Author: Christian Eule ${ }^{1}$
}

\begin{abstract}
The relevance of information technology has steadily increased over past decades. As a result, corporate disclosure about IT governance aspects is of considerable interest to investors. Despite such disclosure being voluntary and not enforced by law, this research investigates whether there is any relation between varying legal disclosure environments and the level of IT governance disclosure by companies. To investigate this relationship, 48 companies' 2015 annual reports are analysed in accordance with an IT governance disclosure framework previously constructed by Bollen et al. (2013). Moreover, the World Bank's Business Extent of Disclosure Index is used as a proxy for legal disclosure environments. The results imply no significant relation between legal disclosure environments and the level of IT governance disclosure which indicates that other factors on the industry and firm-level play a more significant role in determining the level of IT governance disclosure.
\end{abstract}

\section{Introduction}

Over the past three decades, Information Technology (IT) has become increasingly important for companies all over the world. Nowadays, virtually no company can operate without an IT infrastructure that stores and provides relevant information to internal stakeholders to support managers in the decision-making process. As IT became an ever more relevant factor determining a company's business success, IT also became relevant for its external stakeholders. Information about IT and IT governance is of interest especially for investors, who want to assess a company's current condition and its future development. However, as Joshi, Bollen, and Hassink (2013) point out: 'IT governance disclosure is voluntary in nature' (p. 16) and firms are usually not required to disclose any information about IT governance to the public. Intuitively, one might assume that this results in limited information about IT governance being available to investors.

\section{Theory, research questions, and hypotheses}

When it comes to general voluntary disclosure and how it relates to the disclosure environment, empirical evidence is mixed and some studies suggest that a rather lenient regulatory disclosure environment actually encourages voluntary disclosure. With respect to disclosure rules in the US before equity offerings, Shroff, Sun, White, and Zhang (2013) found out that the relaxation of these rules by the SEC resulted in increased voluntary disclosure and reduced information asymmetry. Other researchers (Gordon, Loeb, Lucyshyn, \& Sohail, 2006) discovered that the implementation of the Sarbanes-Oxley Act, which introduced a stricter regulatory regime, significantly increased voluntary disclosure of information security activities.

\footnotetext{
${ }^{1}$ Christian Eule graduated with a bachelor degree in Economics and Business Economics from Maastricht Unviersity in 2017. Currently he takes a Master in International Business with a specialization in Information Management and Business Intelligence at Maastricht University. Contact Information: c.eule@student.maastrichtuniversity.nl or christianeule@gmail.com
} 
Unfortunately, the specific relation between regulatory environments and IT governance disclosure has not yet received much attention by research. While De Haes, Huygh, and Joshi (2017) investigated the IT governance disclosure rates of Belgium firms, thus confining themselves to a single jurisdiction, Bollen et al. (2013) examined IT governance disclosure rates for European and US commercial banks, finding systematic differences in the level of disclosure between the regulatory environments. The aim of this paper is to extend the research by Bollen et al. (2013) to other regulatory environments and a more diverse set of countries to analyse whether systematic differences in the level of IT governance disclosure exist between these countries ${ }^{2}$. For this study, a proxy variable was used to quantify the legal business and disclosure environment of a given country ${ }^{3}$.

As a result, the following research question emerges:

RQ1: To what extent does the legal disclosure environment of a country influence the level of IT governance disclosure by companies subject to that legal disclosure environment?

In their paper, Bollen et al. (2013) put forward a potential explanation of why the assumption they held about the relation between voluntary IT governance disclosure and ownership structure did not hold. The authors hypothesize that the stricter regulations on financial reporting and corporate governance in the U.S. caused American firms to put a stronger focus on statutory disclosure requirements. Hence, the level of voluntary disclosure is lower in areas that are subject to strict regulations. A priori, it is difficult to estimate whether the relation will be positive or negative. On the one hand, stricter regulation might indeed induce companies to focus more on items that are subject to mandatory disclosure rather than on voluntary IT governance disclosure. On the other hand, a stricter regulatory framework might also imply that investors in this economy highly value their protection and respond very positively to further voluntary disclosure. This might cause companies to disclose more about their IT governance on a voluntary basis. Furthermore, IT governance disclosure has value-relevance and the research of Klapper and Love (2002) shows that in countries with weaker legal systems, firm-level corporate governance affects firm value more significantly. If this relation holds for general corporate governance, it might also hold for voluntary IT governance. Therefore, firms subject to weaker legal systems might be induced to disclose more about their IT governance as they could reap higher benefits from doing so. Moreover, there is evidence that firms possess some degree of flexibility and can improve their governance mechanisms even if they are subject to a weak legal system. As a result, one might also observe high levels of IT governance disclosure in countries that have weak legal systems and protection. However, the research results further imply that firms' governance ratings are overall positively correlated with the strength of the legal system in place.

Based on these findings and $R Q 1$, this research aims to test the following hypothesis:

H1: A stronger legal disclosure environment is positively associated with the level of IT governance disclosure.

\footnotetext{
2 Thus, especially the second and fourth point of Maxwell's (2013) theory which may aid my research are relevant here. My research will, to some extent, build upon the research methodology by Joshi et al. and De Haes et al. (2013 \& 2017) since I will apply the framework they constructed to quantify the IT transparency of a company to a more diverse set of institutional settings.

${ }^{3}$ A detailed definition follows in the methodology section.

66 Research

Papers
} 
Finally, the paper aims to answer a second question, i. e.:

RQ2: To what extent do the three roles of IT (automate, informate, and transformate) influence the level of IT governance disclosure?

Chatterjee, Richardson, and Zmud (2001) introduced the IT-driven transformation level as a variable in an OLS regression model to study the way in which announcements of new CIO positions impact a company's stock market returns. The authors characterise industries by three IT strategic roles, namely: automate, informate and transformate 4 . 'Automate' describes an industry where IT only serves to automate business processes and thus replaces human labour. Therefore, digital information is only generated and communicated to a limited extent within as well as between companies. 'Informate' portrays an industry that uses IT to provide data and information to empower managers and employees. Digital information is used more frequently and IT is growing in importance. Finally, an industry in which IT reshapes business processes and relationships, is characterised by a high level of IT-driven transformation and transformates the way business is conducted. In such industries, IT is highly important and may provide a competitive advantage. The findings of Chatterjee et al's study are that the stock market reacts more positively to new CIO position announcements for companies that operate in industries characterised by a high degree of IT-driven transformation. Several other studies hint at the strategic value of IT and differentiate between the above mentioned categories. Anderson, Banker, and $\mathrm{Hu}$ for example (2003) discovered a significant positive relation between IT spending and future earnings for companies operating in both automate and informate industries. However, their findings imply that IT spending increases future earnings more notably in informate industries.

Further studies observed that corporate disclosure practices are influenced by the strategic role IT plays in the industry. Dehning, Richardson, and Zmud (2003) noted that announcements of transformative IT investments by firms in industries in which IT plays a transformative strategic role result in positive abnormal returns. Zmud, Shaft, Zheng, and Croes (2010) observed that companies disclose more about IT in transformate industries than in informate or automate industries. Further empirical evidence is provided by Joshi, Bollen, Hassink, De Haes, and Van Grembergen (2013) who investigated the annual reports of 124 companies to find that, depending on the industry level strategic role of IT, companies in informate and transformate industries disclose significantly more on IT than companies in automate industries.

These findings clearly suggest that companies which operate in an IT-driven, transformative industry, can be expected to disclose more on IT governance than companies operating in automate or informate industries. Two effects might be at play here: Firstly, companies that operate in a transformative industry ${ }^{5}$ naturally work more extensively with data and information technology to be able to operate successfully. As a result, there is simply more to disclose about IT governance and related activities.

4 This characterisation was previously established in different contexts by a.o. Zuboff (1988) and Schein (1992). Schein for example investigated how CEOs view the potential of IT for the business they manage and constructed these three categories accordingly.

5 Such as banks and insurance companies. 
Secondly, the propensity to disclose information about IT governance might be higher due to the fact that IT is a more critical success factor for such businesses. Also, transformate industries are characterised by a more dynamic business environment and more rapid technological change that requires management to reduce information asymmetry by disclosing timely information on a.o. IT governance. Lastly, in transformate industries, IT can be regarded as a more powerful determinant of future business success and therefore investors might focus more on IT governance disclosure. As previous research suggests (Chatterjee et al., 2001 \& Anderson et al., 2003) investors highly value IT information disclosure.

Therefore, the following hypothesis can be derived from $R Q 2$ :

H2: Companies operating in transformate industries have a higher level of IT governance disclosure than companies operating in automate and informate industries.

A third hypothesis can be constructed as a result of the potential interaction between the legal disclosure environment and the IT strategic role. While both might have a direct effect on the level of IT governance disclosure, both independent variables may also depend on each other. Assuming that $H 1$ does hold it might be the case that the IT strategic role moderates the effect of the legal disclosure environment. There could be a potential moderating effect between the two so that organizations which operate in a transformate industry are induced to disclose more about IT regardless of the legal disclosure environment they are subjected to. Such a relation is comparable to the analysis of Joshi et al. (2013) who found that the IT strategic role has a negative (though insignificant) moderating effect on IT governance maturity. Thus, the following hypothesis can be put forward:

H3: The effect of the legal disclosure environment on the level of IT governance disclosure is weaker for companies that do business in transformate industries.

While the design of this study is pretty similar to that of Joshi et al. (2013) with respect to the dependent variable and the independent variable of the industry strategic role ${ }^{6}$, this research, to the best of my knowledge, is the first to combine the IT governance disclosure index with a proxy for the legal disclosure environment and the IT strategic role. Furthermore, the sample is geographically more diversified than most other previous studies on the topic of IT governance disclosure. Lastly, the results by Joshi et al. (2013) were gathered in 2008. As a result, potential new regulations and laws that came into force after the financial crisis were either very new or not yet established and did not yet affect the disclosure practices of firms. This study therefore presents more recent results and insights into the relation between IT governance disclosure, the legal disclosure environment, and the IT strategic role. To conclude, the following model (Figure 1) can be constructed to visually summarize the theory that is being tested:

Figure 1: Visual representation of variables and hypotheses

\footnotetext{
6 Please refer to section 4 for more information on the variables. Marble

68 Research Papers
} 


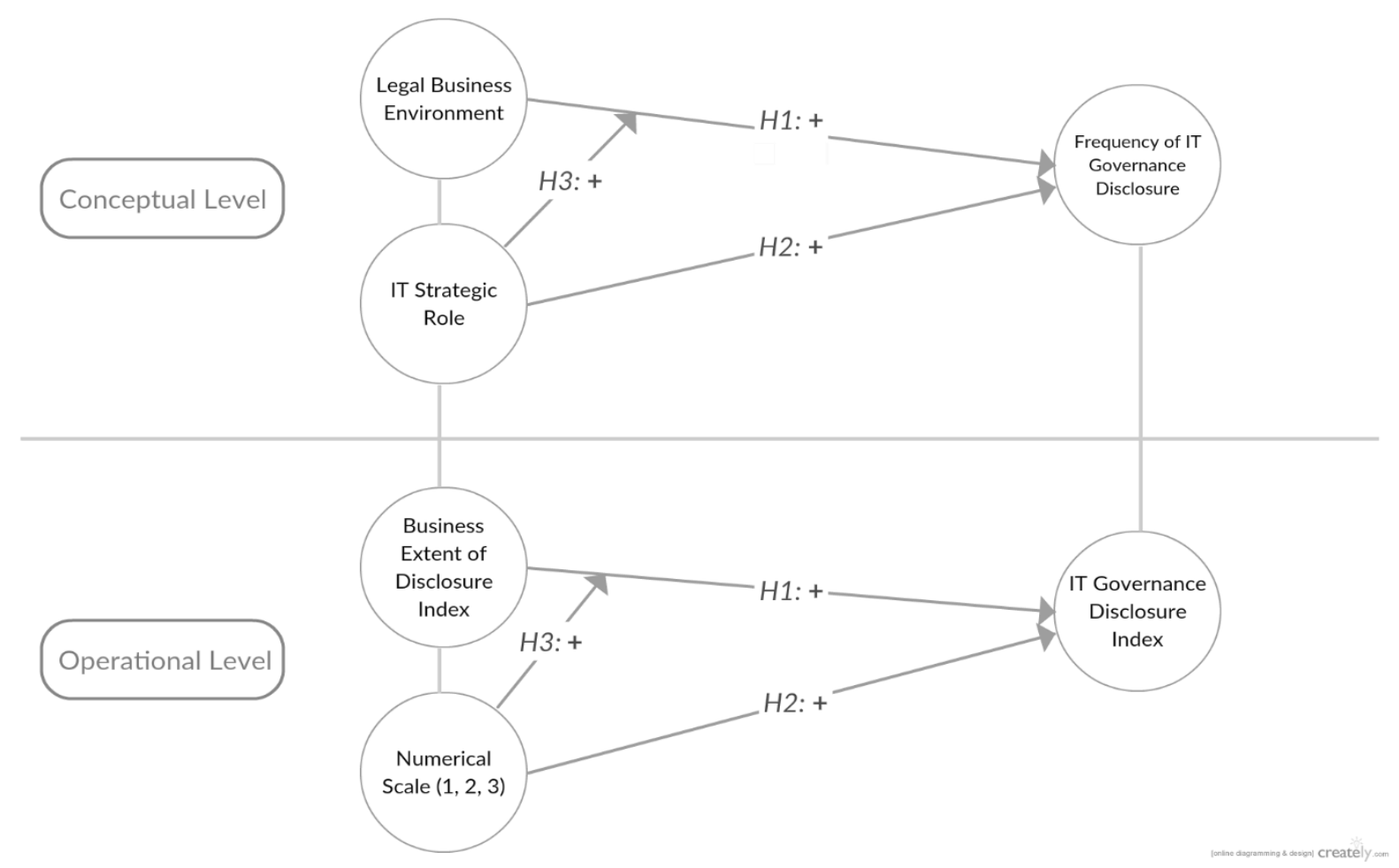

\section{Review of relevant literature}

The following section presents further literature that is relevant to IT governance, IT governance transparency, corporate governance and the external corporate governance environment. Based on previous literature the section highlights why IT governance disclosure in particular is important for organizations and how corporate governance and the external corporate governance environment also play a potentially crucial role in determining the level of voluntary disclosure.

\subsection{IT governance and IT governance transparency}

Webb et al. (2006) attempted to provide a single definition of IT governance that incorporates all relevant aspects. The authors' definition of IT governance is as follows:

IT Governance is the strategic alignment of IT with the business such that maximum business value is achieved through the development and maintenance of effective IT control and accountability, performance management and risk management.

(p. 7)

As such, IT governance can be regarded as a sub-part of corporate governance (De Haes \& Van Grembergen, 2009; Johannsen \& Goeken, 2006) but while general corporate governance is addressed in the regulatory framework of at least 50 countries (Coombes, 2004), the call for IT governance aspects to be incorporated in regulatory frameworks was not addressed by many regulatory frameworks back in 2003 (IT Governance Institute, 2003). Other definitions have been put forward in the academic literature (e.g. Weill \& Ross, 2004; ITGI, 2003) but the above definition suits this study's research goal best. The definition addresses in particular the four areas of IT (Strategic alignment, value delivery, risk 
management, performance measurement) that are also part of the IT governance disclosure framework used in this study.

The importance of proper IT governance has been reinforced by the emergence of several scandals at the beginning of the millennium and during the 2008 financial crisis. ${ }^{7}$ As a response to accounting scandals in the US, federal laws such as the Sarbanes-Oxley Act (SOX) were passed. The Basel III regulatory accord was devised in response to the 2008 banking crisis. Moreover, many countries developed corporate governance codes over the last 15 years to ensure an increased level of transparency in businesses (European Corporate Governance Institute, n. d.). Those developments further reinforced the importance of IT governance because apart from the fact that IT is becoming generally more important for an organization's successful operation (De Haes \& Van Grembergen, 2009), the majority of the new regulations affect IT directly or indirectly according to Johannsen and Goeken (2006, p. 10). As the board of directors has a much bigger interest in the accuracy of the financial reports that have to be submitted, there is an increasing need to prove the appropriateness and correctness of both system development and system operation. Insofar it is safe to assume that a sustainable implementation of the compliance guidelines can be achieved in a meaningful way only by means of an IT governance which manages these tasks on the basis of an adjusted methodology.

There are further studies that point towards the internal and external importance of IT and adequate IT governance for businesses. A study by Weill and Ross (2004) for example shows that organizationally embedded IT governance is associated with higher returns on IT investments and increased profits. The IT Governance Institute (2003) argues that 'adequate governance of the enterprise's IT infrastructure' (p. 11) is necessary to meet stakeholder expectations such as having a sustainable business model and enabling this business model to grow and change. De Haes and Van Grembergen (2009) found that there is a considerable number of IT governance practices which are regarded as effective and easy to implement by Belgian financial services firms.

Since IT governance is a component of corporate governance, IT governance disclosure is a relevant issue, too. Joshi et al. (2013) defined IT governance transparency as:

The extent to which firms provide adequate and relevant IT governance information in a timely and effective manner to their stakeholders, such as investors, policy makers and regulatory bodies so that they can assess management's behavior in using $I T^{\prime}$

(p. 118).

While there are studies on the relation between corporate governance transparency and its effects on a firm's success measured by different variables such as profitability (e.g. Kusumawati, 2007) or firm valuation (Picou \& Rubach, 2006; Healy \& Palepu, 2001), the relevance and implications of IT governance disclosure is immensely under-researched. Raghupathi (2007) stresses that 'transparency and accountability in corporate IT governance are critical to stakeholder confidence and creating a positive image with the general public' (p. 99). As pointed out above, a topic Bollen et al. (2013) shed

7 Among others those scandals include Enron, WorldCom, and Lehman Brothers.

$70 \mid \begin{aligned} & \text { Marble } \\ & \text { Research } \\ & \text { Papers }\end{aligned}$ 
some light on is the relation between the degree of IT governance disclosure and the institutional settings within which IT governance information is disclosed. In their study of 183 commercial banks from Europe and the United States, the authors discovered that European-based commercial banks disclose more information about their IT strategic alignment, IT value delivery, IT risk management, and IT performance measurement than their US counterparts. As outlined above, these results came as a surprise to the authors. They initially assumed that it would be the other way around, i.e. that US-based firms would disclose more information about IT due to the usually less concentrated ownership structure of US firms ${ }^{8}$.

Thus, IT governance and IT governance transparency may be shaped by both the external corporate governance environment as well as general corporate governance practices determined by the organization $^{9}$.

\subsection{Corporate governance}

Numerous researchers and academics provide various definitions of what constitutes corporate governance. Accurate and general definitions are among others provided by the Organization for Economic Co-operation and Development (OECD) (2004) and the Australian Securities Exchange (ASX) Corporate Governance Council (2003). According to the OECD:

Corporate governance involves a set of relationships between a company's management, its board, its shareholders and other stakeholders. Corporate governance also provides the structure through which the objectives of the company are set, and the means of attaining those objectives and monitoring performance are determined. (p. 11)

According to the ASX Corporate Governance Council, corporate governance:

... is the system by which companies are directed and managed. It influences how the objectives of the company are set and achieved, how risk is monitored and assessed, and how performance is optimised. Good corporate governance structures encourage companies to create value (through enterpreneurism, innovation, development and exploration) and provide accountability and control systems commensurate with the risks involved.

(p. 3)

Those definitions clearly highlight that it is of strategic importance to implement corporate governance in order to ensure business success. The definitions further indicate that corporate governance decisions are relevant not only for direct investor relations, but also for the internal functioning of the organization. Various studies suggest that internal corporate governance affects the performance of the

\footnotetext{
8 From previous findings (e.g. Baek, Johnson, \& Kim, 2009; Chau \& Gray, 2002; Eng \& Mak, 2003 and others), which suggest that voluntary disclosure is positively related to outside ownership, the authors inferred that the results might be similar for IT governance disclosure.

${ }^{9}$ Such as decisions on the ownership structure of the organization.
} 
business. Florackis (2005) for example found evidence that 'executive remuneration generates conflicting effects on managerial behaviour that have a measurable impact on corporate efficiency' ( $p$. 5). Further, the author pointed out that debt maturity is a significant predictor of company performance. Evidence suggests that the firm value increases with the level of short-term debt measured as a percentage of total debt which is used as a proxy for company performance in this study. Furthermore, increased institutional ownership and outside directorship (used as measures for corporate governance) favourably impact default risk and bond yields (Bhojraj \& Sengupta, 2003). Hazarika, Karpoff, and Nahata (2012) discovered that boards can proactively influence managers and discipline them in their earnings management before earnings manipulations lead to external consequences. The authors agree with the assertion that internal governance can help mitigate managerial agency problems.

A definition of corporate governance that focuses more specifically on the prominent principal-agent problem and the dispersion of ownership and control was among others outlined by Momot, Vashchenko, Avanesova, and Chudopal (2015) who based their definition on the findings of Brewster, Goergen, and Wood (2012):

Corporate governance deals with the conflicts of interests between the providers of finance and the managers; the shareholders and the stakeholders; different types of shareholders (mainly the large shareholder and the minority shareholders); and the prevention or mitigation of these conflicts of interests.

(p. 212)

Therefore and apart from the internal factors such as control mechanisms and efficiency that can be improved by corporate governance, disclosure on corporate governance helps to reduce information asymmetry between (potential) investors and the organization. If there is not enough information available, or if investors believe that important issues are not disclosed by an organization, they will refrain from investing. The only way a reduction of information asymmetry between the two can be achieved is by financial and non-financial corporate governance disclosure. ${ }^{10}$ Previous studies show that investors generally value corporate governance and its disclosure. In a survey conducted by McKinsey \& Company in 2002, a majority of investors was willing to pay a premium for companies that have high governance standards. The premiums investors were willing to pay ranged from 12 to over 30 percent depending on the geographical location of the investors. According to McKinsey, those values imply that investors assess the corporate governance mechanisms established by a firm just as much as financial indicators when deciding where to invest. Furthermore, there is evidence which suggests that the valuerelevance of non-financial information is significantly higher than that of financial information in the cellular industry (Amir \& Lev, 1996). The authors expect that the findings will be similar in other science-based industries that are characterized by high growth. Lastly, voluntary non-financial disclosure appears to be of value to investors as well (Dhaliwal, Li, Tsang, \& Yang, 2011). The authors reveal that increased voluntary disclosure on corporate social responsibility issues subsequently results in a lower

\footnotetext{
10 This paragraph will focus on findings in the area of non-financial and voluntary disclosure as these findings are the most relevant to IT governance disclosure which is, to a large extent, non-financial and voluntary.
}

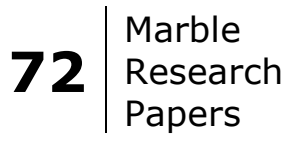


cost of equity capital, which is exploited by the companies concerned through subsequent seasoned equity offerings.

These research results imply that corporate governance and its disclosure is of great importance to any organization that seeks to acquire external capital. To acquire external capital at low costs, organizations need to disclose not only relevant financial information but also relevant non-financial information. Ideally, organizations do not confine themselves to complying merely with statutory disclosure requirements. Rather, organizations should also report on crucial information that is not included in the corporate governance code.

\subsection{The external corporate governance environment}

Lastly, the level of corporate governance disclosure is largely dependent on the external corporate governance environment and corporate governance mechanisms. According to research (Gillan, 2006), corporate governance mechanisms fall into either of two categories: internal or external corporate governance mechanisms. The external governance mechanisms a. o. include laws and regulations, the various external markets such as labor markets, the market for corporate control, or capital markets, the providers of capital market information, and private sources of external oversight (e.g. external lawsuits and the media). Internal governance mechanisms a. o. include the board of directors, the incentives for managers, the capital structure and internal control systems. Gillan (2006) identifies laws and regulations as important external governance mechanisms that have a considerable impact on 'corporate governance and the way that firms operate' (p. 383). Obviously, these two categories do not exist in isolation but are related to each other and have counterparts. Internal control systems can be regarded as the counterpart of laws and regulations as these systems help to ensure organizations' compliance with laws and regulations. Moreover, certain laws and regulations are related to other internal governance mechanisms such as the capital structure of the firm which may be affected by certain laws that e.g. specify a maximum debt-to-equity ratio. Following $R Q 1$, this research will focus its attention on the IT governance transparency mechanism and the way it is impacted by the first category of external governance defined by Gillan (2006) namely, law and regulation.

Academic literature also delved into the cross-country comparison of legal systems with respect to corporate governance to find that investor protection laws differ significantly across countries which is partly attributable to the differences in legal origins (La Porta, Lopez-de-Silanes, Shleifer, \& Vishny, 1997). Consequently, the cross-country differences of legal systems also appear to affect corporate governance mechanisms such as the ownership structure (an internal governance mechanism) and the market for corporate control (an external governance mechanism) (La Porta et al., 2000; Gompers, Ishii, \& Metrick, 2003). Research results of a study by Klapper and Love (2002) indicate that firms in countries with weak overall legal systems have lower governance ratings. When putting these findings into relation with firm performance (measured with Tobin's-Q) the authors discover that firm-level corporate governance more significantly affects firm performance in countries with weak shareholder protection and poor judicial efficiency. As indicated above, the question this paper tries to answer is whether similar findings apply to IT governance transparency. In particular it tries to answer whether firm-level IT governance transparency is significantly affected by the legal system. 


\section{Research methodology}

\subsection{Sample and research design}

The sample for this research consists of 48 companies from eight countries ${ }^{11}$ that were listed on their respective "home" stock exchange in $2015^{12}$. The sample includes financial and non-financial companies. Companies considered for selection needed to be non-governmental, publicly listed, and have an annual report for the financial year of 2015 available in English. There are two straightforward reasons why the annual report instead of any other medium such as companies' websites or press releases was chosen for the analysis. Firstly, the annual reports were chosen because of the limited scope of this research which did not allow for a more extensive analysis of other media. A previous study by Bollen et al. (2013) moreover found that the annual report is the preferred medium used by companies when disclosing about IT governance. Secondly, compared to company websites and press releases, annual reports of listed companies are subject to specific disclosure requirements and standards by the country's and stock exchange's regulatory authorities. Even where IT governance disclosure is voluntary, the impact of the legal business environment on the level of IT governance disclosure is likely to be more clearly reflected in the annual reports than in other media. Furthermore, it was important to have a geographically diversified sample to obtain insights across different continents and countries as well as across varying business and legal environments ${ }^{13}$. To have a symmetric sample design and fairly represent the different IT strategic roles as well as the various legal disclosure environments, a similar amount of companies representing each country and industry strategic role was selected. The countries were selected from the lower and upper end of the Business Extent of Disclosure Index (BEoDI) ${ }^{14}$ of 2015 that is generated by the World Bank on an annual basis for each country. For every country in the sample, six companies were selected, two each operating either in an automate, informate, or transformate industry. The classification of the companies with regard to their IT strategic role was done in accordance with Chatterjee et al. (2001) by analyzing the annual report as well as the website of the firms concerned.

Table 1: Overview of research design and countries included.

\begin{tabular}{lll}
\hline BEoDI & Country & \multicolumn{1}{c}{ IT Strategic Role } \\
\hline 1 & Switzerland & 2 AUTO; 2 INFO; 2 TRANS \\
2 & Philippines &, \\
3 & Kenya &, \\
4 & Netherlands &,- \\
--- & -- &, \\
7 & Nigeria &, \\
8 & Sweden &, \\
9 & Colombia & \\
\hline 10 & Thailand & \\
\hline
\end{tabular}

11 Please refer to Table 1 for a simple overview of the research design and countries.

12 "Home" refers to the national stock exchange of the country where the respective company is headquartered

13 Therefore, two countries from Asia and two from Africa are included in the sample. Moreover, one country from South America and three countries from Europe are included.

${ }^{14}$ For a definition of the BEoDI and more information on the structure please refer to 4.2 and/or Table 2.

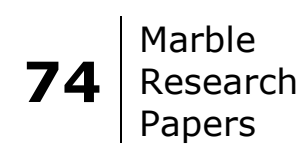




\subsection{Variable definitions and multiple regression models}

The dependent variable of this study is the IT Governance Disclosure Index (ITGDI) ${ }^{15}$ which is computed according to a framework developed by Bollen et al. (2013). This framework was developed based upon four focus areas identified by the ITGI (2003) and contains 39 items ${ }^{16}$. Statistics about the four focus areas are provided in the results section but will not be investigated in more detail due to the limited scope of this research. For each item the assessed whether it is reported in the annual report (score = 1 ) or not (score $=0$ ). The total number of reported items results in a final score for each company that can be transformed into an average. The first independent variable of the model is the BEoDI from 2015 and is retrieved for each of the eight countries included in the sample (World Bank, 2017). The variable is continuous and ranges from 0 to $10^{17}$. For the purposes of the analysis, this variable serves as a proxy for the legal disclosure environment (which as outlined under section 2 and $H 1$ might have an effect on IT governance disclosure). The BEoDI is defined as measuring 'the extent to which investors are protected through disclosure of ownership and financial information' (World Bank, 2017). Moreover, it measures business regulation, and captures the regulatory outcomes of laws. The variable also measures the protection of minority shareholders against the misuse of assets by managers for personal profits. Thus, a score of 10 indicates that the country has extensive disclosure laws in place which are also successfully enforced by regulatory authorities. On the other hand, a score of 0 means that investors are afforded little protection through disclosure and regulation. The BEoDI is used to test $H 1$. To test whether ITGDI differs across industries (H2), three dummy variables are created (namely, AUTO, INFO, and TRANS) which refer to the three distinct industry strategic roles of IT. In order to find out whether there exists an interaction effect between the two independent variables $(H 3)$, two interaction terms are computed (namely, BEoDI $\times$ INFO, and BEoDI $\times$ TRANS). Lastly, each company's size (SIZE) and net profit margin (PROFIT) are used as control variables in the analysis. SIZE is measured on the basis of the number of employees working for the company and was retrieved from the annual reports. The rationale for including SIZE as a control is to generally account for any potential size-effects. For example, larger companies might generally have implemented more sophisticated communication and information systems to successfully coordinate projects. As these companies become more dependent on the functioning of such systems, they might observe the need to disclose more about such systems in their annual report to keep investors informed. The evidence for any effect of company size on information disclosure in general (Zmud et al., 2010), and IT governance disclosure in particular (Joshi et al., 2013) appears to be mixed. To gauge companies' profitability, net profit margins are used as a proxy $^{18}$. PROFIT is the net profit margin of each company measured in percent. For the PROFIT variable, there are three missing values in the data set while for SIZE, there are four missing values in the data set. As no case has a missing value in both variables, this results in a total of seven out of 48 cases (ca. $15 \%$ ) that would have to be excluded from a regression analysis. All missing values were replaced by

\footnotetext{
${ }^{15}$ The natural logarithm of the ITGDI was taken as the dependent variable at a later point in the analysis. Model $1 \mathrm{a}$ and Model $2 \mathrm{a}$ are not suitable for regression analysis as they violate the assumption of homoscedasticity.

${ }_{16}$ Please refer to the paper "An empirical assessment of IT governance transparency: evidence from commercial banking" by Bollen et al. (2013) for a detailed definition of the four focus areas and the 39 items of the framework.

17 The globally diversified sample contains countries from four continents each assuming a value at the lower $(1,2,3,4)$ or upper $(7,8,9,10)$ end of the BEoDI. Switzerland which actually has a value of 0 for the BEoDI was recoded to equal 1 so that a statistical analysis is possible.

18 Which is net income divided by revenue.
} 
the mean, since too much information would be lost if these cases were excluded ${ }^{19}$. PROFIT is included as a control variable since some research showed a significant positive relation between voluntary disclosure and profitability (Haniffa \& Cooke, 2002; Soh, 1996). Again, evidence is however mixed and other research found an insignificant or significant negative relationship (Rouf \& Abdur, 2011; Eng \& Mak, 2003). Table 2 gives an overview and definition of all the relevant variables contained in the model.

In principle, two distinct models are constructed to review whether the three presented hypotheses can be confirmed or rejected. The dependent variable of both models is the ITGDI. Model 1 a tests $H 1$ and $H 2$ while Model $2 \mathrm{a}$ tests $\mathrm{H} 3$ by also containing two interaction variables to test for the potential moderating effect of the IT strategic role on the legal dislcosure environment. Model $1 b$ and Model $2 b$ are not conceptually different from Model $1 \mathrm{a}$ and Model 2a with the alteration that the natural logarithm of the dependent variable is applied (InITGDI) ${ }^{20}$.

Model 1a: ITGDI $=\beta_{0}+\beta_{1} * B E o D I+\beta_{2} * A U T O+\beta_{3} * I N F O+\beta_{4} *$ TRANS $+\beta_{5} * S I Z E+\beta_{6} *$ PROFIT

Model 1b: $\operatorname{lnITGDI}=\beta_{0}+\beta_{1} * B E o D I+\beta_{2} * A U T O+\beta_{3} * I N F O+\beta_{4} *$ TRANS $+\beta_{5} * S I Z E+\beta_{6} *$ PROFIT

Model 2a: ITGDI $=\beta_{0}+\beta_{1} * B E o D I+\beta_{2} * A U T O+\beta_{3} * I N F O+\beta_{4} *$ TRANS $+\beta_{5} * S I Z E+\beta_{6} *$ PROFIT $+\beta_{7} * B E o D I \times$ $I N F O+\beta_{8} * B E O D I \times T R A N S$

Model $2 b: \operatorname{lnITGDI}=\beta_{0}+\beta_{1} *$ BEODI $+\beta_{2} *$ AUTO $+\beta_{3} * I N F O+\beta_{4} *$ TRANS $+\beta_{5} *$ SIZE $+\beta_{6} *$ PROFIT $+\beta_{7} *$ $B E O D I \times I N F O+\beta_{8} * B E O D I \times T R A N S$

Table 2: Overview of variables and definitions

\begin{tabular}{|c|c|c|}
\hline Name & Abbreviation & Type/Definition/Measurement \\
\hline \multicolumn{3}{|l|}{ Dependent Variable } \\
\hline $\begin{array}{l}\text { IT Governance } \\
\text { Disclosure Index }\end{array}$ & ITGDI & $\begin{array}{l}\text { Interval variable/Average score of items on IT governance } \\
\text { disclosure framework/Constructed by coding }\end{array}$ \\
\hline \multicolumn{3}{|l|}{ Independent Variables } \\
\hline $\begin{array}{l}\text { Business Extent of } \\
\text { Disclosure Index }\end{array}$ & BEoDI & $\begin{array}{l}\text { Interval variable/Extent of investor protection via disclosure } \\
\text { regulation/Constructed by World Bank via a.o. surveys }\end{array}$ \\
\hline Automate Industry & AUTO & $\begin{array}{l}\text { Dummy variable/Score of } 1 \text { if company operates in an automate } \\
\text { industry and } 0 \text { otherwise }\end{array}$ \\
\hline Informate Industry & INFO & $\begin{array}{l}\text { Dummy variable/Score of } 1 \text { if company operates in an informate } \\
\text { industry and } 0 \text { otherwise }\end{array}$ \\
\hline $\begin{array}{l}\text { Transformate } \\
\text { Industry }\end{array}$ & TRANS & $\begin{array}{l}\text { Dummy variable/Score of } 1 \text { if company operates in a transformate } \\
\text { industry and } 0 \text { otherwise }\end{array}$ \\
\hline
\end{tabular}

${ }^{19}$ I acknowledge that replacement by the mean is sub-optimal, especially if the number of observations is relatively low. However, neither the mean nor the standard deviation of other key variables changed significantly as missing values were replaced by the mean. Thus, it can be reasonably assumed that the values are missing at random.

${ }^{20}$ Models $1 \mathrm{~b}$ and $2 \mathrm{~b}$ were constructed post-hoc because the assumption of homoscedasticity is violated under Model $1 \mathrm{a}$ and $2 \mathrm{a}$.

$76 \begin{aligned} & \text { Marble } \\ & \text { Research } \\ & \text { Papers }\end{aligned}$ 


\begin{tabular}{|c|c|c|}
\hline \multicolumn{3}{|l|}{ Control Variables } \\
\hline Company Size & SIZE & $\begin{array}{l}\text { Interval variable/Number of employees working for the } \\
\text { company/Data is retrieved from the annual reports }\end{array}$ \\
\hline Company Net Profit & PROFIT & $\begin{array}{l}\text { Interval variable/Net profit (or equivalent) for the financial year in } \\
€ / \text { Data is retrieved from the annual reports }\end{array}$ \\
\hline \multicolumn{3}{|l|}{ Additional Variables } \\
\hline $\begin{array}{l}\text { IT Strategic } \\
\text { Alignment } \\
\text { Disclosure Index }\end{array}$ & ITSA & $\begin{array}{l}\text { Interval variable/Average score for strategic alignment focus area } \\
\text { of IT/Constructed by coding }\end{array}$ \\
\hline $\begin{array}{l}\text { IT Value Delivery } \\
\text { Disclosure Index }\end{array}$ & ITVD & $\begin{array}{l}\text { Interval variable/Average score for value delivery focus area of } \\
\text { IT/Constructed by coding }\end{array}$ \\
\hline $\begin{array}{l}\text { IT } \\
\text { Management }\end{array}$ & ITRM & $\begin{array}{l}\text { Interval variable/Average score for risk management focus area of } \\
\text { IT/Constructed by coding }\end{array}$ \\
\hline Disclosure Index & & \\
\hline $\begin{array}{l}\text { IT Performance } \\
\text { Measurement }\end{array}$ & ITPM & $\begin{array}{l}\text { Interval variable/Average score for performance measurement } \\
\text { focus area of IT/Constructed by coding }\end{array}$ \\
\hline Disclosure Index & & \\
\hline
\end{tabular}

\section{Results}

Section 5 presents the results of the research. It first portrays relevant observations from the descriptive statistics. Then some analysis is conducted by running a Mann-Whitney $U$ test and a one-way ANOVA test. The correlation statistics between the variables that are relevant for the hypotheses are also investigated. Lastly, all three hypotheses are tested by running multiple regression tests.

\subsection{Descriptive statistics and preliminary statistical tests}

After accounting for missing values by mean replacement, the sample contains 48 companies. Summary statistics on the dependent variable as well as on all other non-dummy variables are provided in Table 3. The mean value for the ITGDI is .22 or $22 \%$ which suggests that on average companies reported on ca. 9 out of 39 items of the IT governance disclosure framework. Joshi et al. (2013) found that among the 124 companies in their sample, the average number of items reported was 6 out of 39. Furthermore, the sample contains two companies that did not report on any of the 39 items. The company with the highest ITGDI communicated on 22 out of 39 items in their 2015 annual report. The standard deviation of the ITDI is 0.15 indicating a relatively high variation. Due to the sample design, the BEoDI is not relevant for discussion here. SIZE has a mean of 15899 and the company with the highest number of employees was Ahold NV from the Netherlands with a workforce of 236,000. The average net profit margin (PROFIT) is ca. $1.02 \%$ and has a standard deviation of ca. $49.38 \%$. With regard to the IT focus areas, ITRM scored highest on average $(M=0.28, S D=0.28)$ followed by ITPM $(M=0.24, S D=0.15)$. 
Table 3: Summary statistics

\begin{tabular}{lcclll}
\hline \multicolumn{1}{l}{$\mathrm{N}$} & Minimum & Maximum & Mean & Std. Deviation \\
\hline $\begin{array}{l}\text { Dependent Variable } \\
\text { ITGDI }\end{array}$ & 48 & 0 & & & \\
\hline Independent and Control Variables & & .56 & .22 & .150 \\
\hline BEoDI & 48 & 1 & 10.00 & 5.50 & 3.235 \\
SIZE & 48 & 44 & 236000 & 15899 & 36725.433 \\
PROFIT & 48 & -299 & 63.54 & 1.0231 & 49.377 \\
\hline Additional Variables & & & & & \\
\hline ITSA & 48 & .00 & .55 & .1515 & .14687 \\
ITVD & 48 & .00 & .77 & .2276 & .22269 \\
ITRM & 48 & .00 & .86 & .2827 & .27878 \\
ITPM & 48 & .00 & .63 & .2422 & .15125 \\
\hline
\end{tabular}

The correlation statistics for the dependent, independent and control variables are shown in Table 4. Of particular interest in this table is the first row which portrays the Pearson correlation between the dependent variable and all the other variables in the model. The correlation coefficient for the BEoDI indicates a clearly non-significant trend in the direction predicted by $H 1$ (corr $=0.014, p=0.927$ ). With regard to the second independent variable, Table 4 suggests that AUTO has a negative correlation with ITGDI that is significant at the $1 \%$ level (corr $=-0.486, p=0.000$ ). INFO is not associated to a significant degree with ITGDI (corr $=-0.181, \quad p=0.219$ ) while TRANS is significantly and positively correlated with ITGDI (corr $=0.667, p=0.000$ ). Finally, the correlation of SIZE with ITGDI is marginally significant at the $10 \%$ level (corr $=0.245, p=0.093$ ) and PROFIT is not considerably related to ITGDI (corr $=0.065, p=0.659$ ). Overall, the correlation statistics indicate that there is probably no support for $H 1$ while there definitely appears to be some support for $H 2$.

Table 4: Bivariate correlation statistics of the dependent and independent variables $(n=48)$

\begin{tabular}{lllllll}
\hline & ITGDI & BEoDI & AUTO & INFO & TRANS & SIZE \\
\hline BEODI & .014 & & & & & \\
AUTO & $-.486^{* * *}$ & .000 & & & \\
INFO & -.181 & .000 & $-.500^{* * *}$ & & \\
TRANS & $.667^{* * *}$ & .000 & $-.500^{* * *}$ & $-.500^{* * *}$ & & \\
SIZE & .245 & -.096 & -.106 & .114 & -.008 & \\
PROFIT & .065 & -.054 & .101 & $-.270^{*}$ & .169 & .050 \\
\hline
\end{tabular}

A Mann-Whitney $U$ test and one-way ANOVA test provide further information on the relation between the ITGDI and the BEoDI, as well as between the ITGDI and the three IT strategic roles. The results for both tests are displayed in Table 5 and Table 6 (Table 5 for the Mann-Whitney $U$ test and Table 6 for the one- 
way ANOVA test). To conduct the Mann-Whitney $U$ test $^{21}$, the data is split into two groups: countries with a low BEoDI (LBEoDI) and countries with a high BEoDI (HBEoDI). They serve as proxies for countries having a weak legal dislcosure environment versus those being characterised as having a strong legal disclosure environment. Since the countries are already split due to scope reasons, the LBEoDI-group includes four countries for the BEoDI-values from one to four. The HBEoDI-group includes four countries with BEoDI-values from seven to ten ${ }^{22}$. This results in each group containing 24 observations. Panel A of Table 5 indicates that the mean rank for the countries having a high BEoDI is slightly higher than that of countries having a low BEoDI. However, the Mann-Whitney $U$ statistic and the associated exact p-value of 0.866 (two-tailed) clearly indicate that the results obtained are insignificant and based on the underlying data; the alternative hypothesis of a significant difference in the mean ranks between the two groups is rejected. These results are in line with the correlation statistic of 0.014 obtained in Table 4 which also shows a positive, but clearly insignificant relation between the BEoDI and ITGDI. Again, the results do not indicate support for $H 1$.

Table 5: Mann-Whittney U between BEoDI and ITGDI

Panel $A$

\begin{tabular}{lllll}
\hline & LEVEL & $\mathrm{N}$ & Mean Rank & Sum of Ranks \\
\hline ITGDI & Low & 24 & 24.15 & 579.50 \\
& High & 24 & 24.85 & 596.50 \\
& Total & 48 & & \\
\hline
\end{tabular}

Panel B

\begin{tabular}{ll}
\hline Test Statistics & ITGDI \\
\hline Mann-Whitney U & 279.500 \\
Wilcoxon W & 579.500 \\
Z & -.176 \\
Asymp. Sig. (2-tailed) & .861 \\
Exact Sig. (2-tailed) & .866 \\
\hline
\end{tabular}

a. Grouping Variable: LEVEL

Next, a one-way ANOVA test is performed to provide more insights on the relation between the IT industry strategic role and the ITGDI. The three independent groups in this analysis are the companies that are classified as either operating in an automate, informate, or transformate industry. As a result, each of the three groups contains 16 observations. The output and post-hoc tests for the one-way ANOVA test are displayed in Table 6 below. Due to the necessity of logarithmic transformation ${ }^{23}$ there $^{2}$

\footnotetext{
${ }^{21}$ This non-parametric test was conducted instead of the independent samples t-test because, unlike the HBEoDI-group the LBEoDI-group did not have a normal distribution. As both groups have distributions that are shaped differently, only a mean rank analysis can be provided in Table 5.

22 Also refer to Table 1.

${ }^{23}$ All assumptions with the exception of the homogeneity of variances assumption are satisfied. To tackle the problem of the groups having unequal variances, the dependent variable is altered via logarithmic
} 
are now only 46 observations as two cases had to be excluded (the dependent variable now is InITGDI). Panel A reveals that there is a significant overall difference in the means of the three groups $(F=$ 11.508, $p=0.00)$. The post-hoc test in Panel B shows the direction of the differences in means. While the mean difference between AUTO and INFO is not statistically significant $(p=0.259)$, the mean difference between AUTO and TRANS as well as INFO and TANS are both significant with $p$-values equal to $0 \%$ and $0.7 \%$, respectively. The signs of the mean differences moreover indicate that the mean of the InITGDI for the companies classified as TRANS is significantly higher than the mean of both of the other groups (i.e. AUTO and INFO). This result provides clear support for $H 2$.

Table 6: One-way ANOVA and Tukey post-hoc test between IT industry strategic role and ITGDI Panel A

\begin{tabular}{llllll}
\hline & Sum of Squares & $\mathrm{df}$ & Mean Square & $\mathrm{F}$ & Sig. \\
\hline Between Groups & 7.456 & 2 & 3.728 & 11.508 & .000 \\
Within Groups & 13.930 & 43 & .324 & & \\
Total & 21.386 & 45 & & & \\
\hline
\end{tabular}

Panel B: Tukey post-hoc test

\begin{tabular}{lllll} 
INDUSTRY $(\mathrm{I})$ & INDUSTRY $(\mathrm{J})$ & Mean Difference $(\mathrm{I}-\mathrm{J})$ & Std. Error & Sig. \\
\hline AUTO & INFO & -.33207 & .20829 & .259 \\
& TRANS & $-.97439^{*}$ & .20829 & .000 \\
\hline INFO & AUTO & .33207 & .20829 & .259 \\
& TRANS & $-.64232^{*}$ & .20123 & .007 \\
\hline TRANS & AUTO & $.97439^{*}$ & .20829 & .000 \\
& INFO & $.64232^{*}$ & .20123 & .007 \\
\hline
\end{tabular}

*. The mean difference is significant at the 0.05 level.

transformation. As a result, the Levene statistic is 0.728 and the assumption of homogenous variances is fulfilled.
$80 \mid$\begin{tabular}{l|l} 
Marble \\
Research
\end{tabular}
Papers 


\subsection{Multiple regression analysis to test models $1 \mathrm{a}, 1 \mathrm{~b}, 2 \mathrm{a}$, and $2 \mathrm{~b}$}

As described in Section 4.2, multiple linear regression models are run to test the three hypotheses postulated in Section 2. Model 1 a aims to test $H 1$ and $H 2$, while Model $2 a$ aims to test $H 3$ by also adding two interaction variables to the first model. The regression output for Model $1 \mathrm{a}$ is shown in Table 7.

Table 7: Multiple linear regression output for ITGDI vs. BEoDI, AUTO

INFO, SIZE, and PROFIT (Model 1a)

Panel A

\begin{tabular}{lllll}
\hline Model & $\mathrm{R}$ & R Square & $\begin{array}{l}\text { Adjusted } \\
\text { Square }\end{array}$ & $\begin{array}{l}\text { RStd. Error of the } \\
\text { Estimate }\end{array}$ \\
\hline $1 \mathrm{a}$ & $.742^{\mathrm{a}}$ & .551 & .495 & .108 \\
\hline
\end{tabular}

Panel B: ANOVA

\begin{tabular}{lllllll}
\hline Model & & Sum of Squares & $\mathrm{df}$ & Mean Square & $\mathrm{F}$ & Sig. \\
\hline $1 \mathrm{a}$ & Regression & .574 & 5 & .115 & 9.812 & $.000^{\mathrm{b}}$ \\
& Residual & .468 & 40 & .012 & & \\
& Total & 1.042 & 45 & & & \\
\hline
\end{tabular}

Panel C: Coefficients ${ }^{a}$

\begin{tabular}{|c|c|c|c|c|c|c|c|}
\hline \multirow[b]{3}{*}{ Model } & & \multirow{2}{*}{\multicolumn{2}{|c|}{$\begin{array}{l}\text { Unstandardized } \\
\text { Coefficients }\end{array}$}} & \multirow{2}{*}{$\begin{array}{l}\text { Standardized } \\
\text { Coefficients }\end{array}$} & \multirow[b]{3}{*}{$\mathrm{t}$} & \multirow[b]{3}{*}{ Sig. } & \multirow{3}{*}{$\begin{array}{l}\text { Collinearity } \\
\text { Statistics } \\
\text { VIF }\end{array}$} \\
\hline & & & & & & & \\
\hline & & $B$ & Std. Error & Beta & & & \\
\hline \multirow[t]{6}{*}{$1 a$} & (Constant) & .303 & .045 & & 6.699 & .000 & \\
\hline & BEoDI & .003 & .005 & .071 & .648 & .521 & 1.084 \\
\hline & AUTO & -.229 & .039 & -.726 & -5.922 & .000 & 1.337 \\
\hline & INFO & -.171 & .041 & -.523 & -4.154 & .000 & 1.411 \\
\hline & SIZE & $1.892 \mathrm{E}-6$ & .000 & .218 & 2.014 & .051 & 1.041 \\
\hline & PROFIT & .001 & .001 & .097 & .865 & .392 & 1.127 \\
\hline
\end{tabular}

All assumptions with the exception of homoscedasticity are fulfilled ${ }^{24}$. Therefore, the natural logarithm of the ITGDI (InITGDI) is again used as a dependent variable in a second regression analysis (Model $1 \mathrm{~b}$, Table 8) that is otherwise similar to Model $1 a$.

\footnotetext{
${ }^{24}$ Both graphs (i.e. standardized residuals vs. standardized predicted values) as well as relevant test statistics such as the Koenker test for heteroscedasticity $(p<0.05)$ indicate the prevalence of heteroscedasticity.
} 
Table 8: Multiple linear regression output for InITGDI vs. BEoDI, AUTO

INFO, SIZE, and PROFIT (Model 1b)

Panel A

\begin{tabular}{llll}
\hline Model & $\mathrm{R}$ & R Square & Adjusted \\
\hline $\mathrm{b}$ & $.654^{\mathrm{a}}$ & .427 & .352 \\
\hline
\end{tabular}

Panel B: ANOVA

\begin{tabular}{lllllll}
\hline Model & & Sum of Squares & df & Mean Square & $F$ & Sig. \\
\hline 1b & Regression & 8.960 & 5 & 1.792 & 5.667 & $.001^{\mathrm{b}}$ \\
& Residual & 12.017 & 38 & .316 & & \\
& Total & 20.977 & 43 & & & \\
& & & & & & \\
\end{tabular}

Panel C: Coefficients ${ }^{a}$

\begin{tabular}{|c|c|c|c|c|c|c|c|}
\hline \multirow[b]{3}{*}{ Mode } & & \multirow{2}{*}{\multicolumn{2}{|c|}{$\begin{array}{l}\text { Unstandardized } \\
\text { Coefficients }\end{array}$}} & \multirow{2}{*}{\multicolumn{2}{|c|}{$\begin{array}{l}\text { Standardized } \\
\text { Coefficients }\end{array}$}} & \multirow[b]{3}{*}{ Sig. } & \multirow{3}{*}{$\begin{array}{l}\text { Collinearity } \\
\text { Statistics } \\
\text { VIF }\end{array}$} \\
\hline & & & & & & & \\
\hline & & $\bar{B}$ & Std. Error & \multirow[t]{2}{*}{ Beta } & $\mathrm{t}$ & & \\
\hline \multirow[t]{6}{*}{$\overline{1 b}$} & (Constant) & -1.498 & .235 & & -6.361 & .000 & \\
\hline & BEoDI & .030 & .027 & .142 & 1.118 & .271 & 1.071 \\
\hline & AUTO & -.920 & .208 & -.621 & -4.417 & .000 & 1.309 \\
\hline & INFO & -.617 & .214 & -.416 & -2.879 & .007 & 1.385 \\
\hline & SIZE & $6.761 \mathrm{E}-6$ & .000 & .172 & 1.378 & .176 & 1.039 \\
\hline & PROFIT & .005 & .004 & .157 & 1.208 & .235 & 1.117 \\
\hline
\end{tabular}

The transformation helps to solve the problem of heteroscedasticity (resulting Koenker- $\chi^{2}=6.376, p=$ 0.382 ). When the regression output for both models is compared, the most notable differences are that the R-squared decreases from Model $1 \mathrm{a}$ to Model $1 \mathrm{~b}$ while the significance of SIZE changes from being significant at $a=0.10(p=0.051)$ to being insignificant $(p=0.176)$. Furthermore, the $p$-value of the BEoDI decreases but remains insignificant $(p=0.271)$.

In this examination, heteroscedasticity was taken into account and two influential outliers were also removed from the data set. The number of observations (N) is thus 46 in Table 7 and 44 in Table 8 as two further companies with an ITGDI of zero had to be removed to calculate the natural logarithm of ITGDI. These two companies may also partly account for the observed differences between Model 1a and $1 \mathrm{~b}$, however it is not possible to isolate their effect. Moreover, Panel $\mathrm{C}$ of Table 7 indicates that multicollinearity is not an issue with the underlying data as the variance inflation factors of all independent and control variables are well below the cut-off values ( i.e. VIF $=6$ and VIF $=10$ ). The 
following text reports the results for Model $1 \mathrm{~b}$ as this is the valid regression analysis that fulfils all necessary assumptions.

Overall, the six predictor variables are jointly significant $(F=5.667, p=0.001)$ meaning that the model predicts values of InITGDI better than the mean of InITGDI. The R-squared equals 0.427 indicating that Model 1b can reasonably explain some of the variation in InITGDI. Panel C of Table 8 provides insight on the answers to the first two hypotheses. As shown above, the coefficient for BEoDI (0.03) is insignificant $(p=0.271)$. This result is in accordance with the outcome of the Mann-Whittney $U$ test conducted in Section 5.1. $\mathrm{H} 1$ is therefore rejected and the BEoDI as a proxy for the strength of the legal disclosure environment does not have a significant effect on the extent of IT disclosure by companies. The output however shows support for $H 2$. TRANS serves as a baseline for the IT strategic role and the coefficients of AUTO $(-0.920, p=0.000)$ and INFO $(-0.617, p=0.007)$ indicate that companies which operate in industries characterised by a lower dependency on and strategic relevance of IT indeed disclose less about IT-related aspects in their annual reports. Moreover, the effect of the industry classification is higher in absolute terms for automate industries than for informate industries. Those results are in line with the post-hoc test of one-way ANOVA analysis implemented in Section 5.1 and $H 2$ is accepted. Lastly, SIZE and PROFIT which are included as control variables in Model $1 \mathrm{~b}$ are not significant and do not help to predict the level of ITGDI ( $p=0.176$ and $p=0.235$, respectively).

Lastly, a test was run to establish whether there is an interaction effect that might moderate the influence of the BEoDI on the ITGDI via the IT strategic role. This investigation helps to confirm or reject $\mathrm{H} 3$ and the model is similar to Model $1 \mathrm{~b}$ with the exception of two interaction terms that are being added. The regression output for Model $2 \mathrm{~b}$ is shown in Table 9.

Table 9: Multiple linear regression output for InITGDI vs. BEoDI, AUTO, INFO, SIZE, PROFIT, BEoDIINFO, and BEoDITRANS (Model 2b)

Panel $A$

\begin{tabular}{lllll}
\hline Model & $\mathrm{R}$ & R Square & $\begin{array}{l}\text { Adjusted } \\
\text { Square }\end{array}$ & $\begin{array}{l}\text { RStd. Error of the } \\
\text { Estimate }\end{array}$ \\
\hline $\mathrm{2b}$ & $.679^{\mathrm{a}}$ & .461 & .357 & .56019 \\
\hline
\end{tabular}

Panel B: ANOVA

\begin{tabular}{|c|c|c|c|c|c|c|}
\hline \multicolumn{2}{|c|}{ Model } & \multirow{2}{*}{\multicolumn{2}{|c|}{$\begin{array}{ll}\text { Sum of Squares } & \mathrm{df} \\
9.680 & 7\end{array}$}} & \multirow{2}{*}{$\begin{array}{l}\text { Mean Square } \\
1.383\end{array}$} & \multirow{2}{*}{$\begin{array}{l}F \\
4.406\end{array}$} & \multirow{2}{*}{$\frac{\text { Sig. }}{.001^{\mathrm{b}}}$} \\
\hline $2 b$ & Regression & & & & & \\
\hline & Residual & 11.297 & 36 & .314 & & \\
\hline & Total & 20.977 & 43 & & & \\
\hline
\end{tabular}


Panel C: Coefficients ${ }^{a}$

\begin{tabular}{|c|c|c|c|c|c|c|c|}
\hline \multirow[b]{2}{*}{ Mode } & & \multicolumn{2}{|c|}{$\begin{array}{l}\text { Unstandardized } \\
\text { Coefficients }\end{array}$} & \multicolumn{2}{|l|}{$\begin{array}{l}\text { Standardized } \\
\text { Coefficients }\end{array}$} & \multirow[b]{2}{*}{ Sig. } & \multirow{2}{*}{$\begin{array}{l}\text { Collinearity } \\
\text { Statistics } \\
\text { VIF }\end{array}$} \\
\hline & & B & Std. Error & Beta & $\mathrm{t}$ & & \\
\hline \multirow[t]{8}{*}{$2 b$} & (Constant) & -1.619 & .301 & & -5.374 & 000 & \\
\hline & BEoDI & -.025 & .046 & -.119 & -.548 & .587 & 3.168 \\
\hline & AUTO & -.500 & .412 & -.337 & -1.213 & .233 & 5.170 \\
\hline & INFO & -.727 & .424 & -.491 & -1.714 & .095 & 5.477 \\
\hline & SIZE & $6.970 \mathrm{E}-6$ & .000 & .178 & 1.417 & .165 & 1.052 \\
\hline & PROFIT & .006 & .004 & .203 & 1.429 & .162 & 1.347 \\
\hline & BEoDIINFO & .095 & .068 & .451 & 1.406 & .168 & 6.866 \\
\hline & BEoDITRANS & .073 & .064 & .348 & 1.149 & 258 & 6.121 \\
\hline
\end{tabular}

a. Dependent Variable: InITGDI

R-squared increases to 0.61 while R-squared adjusted rises marginally to 0.357 compared to Model $1 \mathrm{~b}$ (which is interesting since both added predictors are not significant when being considered on their own). Again, the eight predictors are jointly significant and help to predict InITGDI ( $F=4.406, p=$ 0.001). Strikingly, while all predictors simultaneously are significant, the output in Panel $C$ suggests that when the two interaction terms (BEoDIINFO and BEoDITRANS with BEoDIAUTO as ) are added, there is no single predictor that is significant at $a=0.05$. The only predictor that is significant at $a=0.10$ is INFO which has a negative effect on InITGDI when TRANS is taken as the reference category. Both added interaction variables are insignificant ( $p=0.168$ for BEoDIINFO, and $p=0.258$ for BEoDITRANS) and the positive coefficient of 0.073 for BEoDITRANS actually contradicts $H 3$, showing that the BEoDI as a proxy for the legal disclosure environment has a stronger effect on InITGDI if the company is operating in a transformate industry. Overall, Model $2 \mathrm{~b}$ might suffer from multicollinearity as the VIFs of all three independent variables increase considerably when being compared to Model $1 \mathrm{~b}$. The VIFs for the interaction terms are above the cut-off value of 6. A Pearson correlation table between all variables indicates that the high VIFs mainly originate from a high correlation between the interaction terms with the BEODI, AUTO, INFO, and TRANS variable. The high correlation is a logical result of the way in which the interaction terms are computed.

To isolate the effect of the IT strategic role, two further regressions with InITGDI as the dependent variable are run. The first regression model includes the BEoDI as the independent variable and SIZE and PROFIT as control variables. This model has very weak predictive power and the hypothesis that none of the three predictors is useful in forecasting InITGDI simultaneously cannot be rejected $(F=$ $1.858, p=0.152, \boldsymbol{R}^{2}=0.122$ ). The second model includes AUTO, INFO and TRANS as the independent variables (TRANS is again used as baseline) and SIZE and PROFIT as control variables. The resulting output indicates an overall significance for all predictor variables considered jointly $(F=6728, p=$ $0.000, R^{2}=0.408$ ) and for all three independent variables individually. The R-squared of the second model which leaves out the BEoDI is 0.408 while the R-squared of Model $1 \mathrm{~b}$ (Table 8 ) is 0.427 . These results clearly indicate that the IT strategic role is the single best predictor in the analysis. 


\section{Discussion, limitations, future research}

Investigating the relation between legal business and disclosure environments and the extent of voluntary disclosure on IT governance is the aim and primary purpose of this research $(H 1)$. Additionally, this paper tries to test the robustness of previous findings (Joshi et al., 2013) which indicated that the IT strategic role on an industry-level plays an important part in affecting the level of IT governance disclosure $(H 2)$. Finally, this study reviews whether the IT strategic role moderates the effect of the legal environment on voluntary IT disclosure.

Based on the results presented in Section 5, the answer to the first research question is that the legal disclosure environment of a country does not influence the level of IT governance disclosure by companies that operate in the environment concerned when the BEoDI is used as a proxy for such legal environment. Therefore, $\mathrm{H} 1$ is rejected based on both a preliminary statistical test (Table 5 ) as well as a multiple regression (Table 7). Several reasons might potentially account for the insignificance of the results:

First and foremost, the independent variable of this study measures the level of voluntary disclosure with respect to IT. However, the proxy BEoDI which captures the level of investor protection through disclosure laws focuses, by definition, on mandatory disclosure. Thus the effects of the BEoDI on the ITGDI can only be of an indirect nature and do not affect ITGDI directly. Such indirect effects might have been observed by Bollen et al. (2013) where a potential reason for the higher level of IT governance disclosure among European banks might have been a result of American banks focusing too much on mandatory disclosure and thus reporting less on voluntary disclosure. Such a "focus-effect" is not observed for the data in this study. Another potential indirect effect might be that as a result of stricter regulations, companies are required to put mechanisms and systems in place that help them to not only comply with mandatory disclosure requirements but, as a "side-effect", also generate data and information that is relevant for voluntary disclosure. Hence, there might be economies of scope with respect to such information which facilitates voluntary disclosure eventuating in a higher level of IT governance disclosure. These two indirect effects of a stricter legal disclosure environment might offset each other, resulting in inconclusive evidence. Future research may try to capture and analyse such indirect effects to obtain more information on the relation between legal disclosure environments and voluntary IT governance disclosure.

Secondly, the BEoDI may not be the optimal proxy for the legal disclosure environment and may be the research design of this study is too broad, in that it attempts to measure too many effects at the country level that do not have a strong enough impact on industries and companies. Gordon et al. (2006) for example found a significant relation between the implementation of the SOX and the voluntary disclosure of information security activities of firms. The research design of that event study is more narrowly defined as they only observe the effects of the implementation of a single regulatory act. Moreover, the dependent variable used by the authors is more narrowly defined since it is concerned 
only with the dimension of information security activities while in the present study the measurement of the ITGDI is based on four focus areas of IT governance ${ }^{25}$.

The second research question can be conclusively answered based on the output presented in Tables 6 and 7. The IT strategic role significantly influences the level of IT governance disclosure. Moreover, $H 2$ can be confirmed and the level of the ITGDI differs systematically among the industry strategic roles. Companies operating in transformate industries are indeed found to have the highest level of ITGDI, followed by companies in informate industries (Table 7). This finding is in accordance with previous studies (Joshi et al., 2013; and Zmud et al., 2010) which imply that the transformative nature of IT on the industry level has a positive effect on the level of IT governance disclosure. This study helps to manifest the robustness of such findings since it is (to the best of my knowledge) the first one to apply the concept of IT strategic role on an industry level to a broad variety of countries. The countries in this study differ geographically, culturally and with respect to their level of development. Still, the IT strategic role is found to be a significant predictor of IT governance disclosure.

Lastly, $\mathrm{H3}$ has to be rejected according to the statistical output presented in Table 9. The effect of the legal disclosure environment on the level of IT governance disclosure is thus not moderated by the industry IT strategic role, if the BEoDI is used as a proxy. Those results do not come as a surprise as the effect of the BEoDI itself on IT governance disclosure is found to be insignificant under $H 1$. A similar insignificant effect of moderating variables was found by Joshi et al. (2013). Cleary, the IT strategic role composed of three dummy variables (AUTO, INFO, TRANS) is the single best predictor in the model (Table 8) and apparently industry and business environment factors (industry level) do have a more profound impact on voluntary IT governance disclosure than the legal disclosure environment (country level).

The theoretical implications of this study are that the legal disclosure environments which govern mandatory disclosure requirements are of limited relevance in determining the degree of voluntary IT governance disclosure of companies. It appears that industry level factors such as the type of industry companies operate in play a more significant role and affect the level of IT governance disclosure. Thus, this research has an important implication for policy-makers. To do justice to the increasing importance and relevance of IT disclosure (Raghupathi, 2007), it is not enough for policy-makers to simply rely on increasing disclosure requirements (e.g. for finance) and hope for positive indirect effects of such actions on voluntary IT disclosure. Instead, to prevent any adverse indirect effects of stricter non-IT related regulations and to mitigate risks, policy-makers should take action making it mandatory to disclose certain aspects in the IT risk management dimension. This suggestion is especially relevant for e.g. the banking industry as it is subject to higher operational and systemic risks of IT (Hinz, 2005). Since the banking industry still shows a severe lack of voluntary disclosure with respect to IT governance aspects (this paper $^{26}$ and Bollen et al., 2013) it is difficult for policy-makers, central banks, and investors to

${ }^{25}$ Four other regressions were conducted, testing the significance of the effect of the BEoDI on ITSA, ITVD, ITRM and ITPM to more narrowly investigate the effect on focus areas, however, the BEoDI was still not found to be significant on any of the four areas $(a=0.05)$.

${ }^{26}$ For this study, 12 banks and insurances were analysed, having an average ITGDI of 0.36 .

$86 \mid \begin{aligned} & \text { Marble } \\ & \text { Research } \\ & \text { Papers }\end{aligned}$ 
assess a bank's exposure to such risk. Accordingly, the results of this study encourage policy-makers to mandate aspects from the IT risk management dimension in particular.

An already mentioned limitation of this study lies in the fact that the use of the BEoDI does not seem to be an optimal proxy for the strictness of the legal disclosure environment. Secondly, the scope of this research is very narrow. With the BEoDI as the main variable on the model other potential factors that affect the level of IT governance disclosure such as IT governance maturity variables are not regarded in the analysis. Furthermore, the original sample consists of only 48 observations of which four are left out in the analysis. Thus, the robustness of the regression results obtained is rather limited and results might not be entirely representative. Next, the coding procedure required to construct the ITGDI is by nature a subjective process since it is conducted by the researcher ${ }^{27}$. For this reason the results of this study are not fully comparable with the results of other studies. In Section 5.1 it is mentioned that a previous study by Joshi et al. (2013) found that on average 6 out of 39 items of the IT governance disclosure framework were reported among 124 companies. The data underlying the present study reveals an average of 9 out of 39 items. One reason for the divergence might simply lie in a different approach to the rating of the 39 items instead of the average ITGDI being de facto different. Another reason might be that the companies of both samples differ systematically which results in a higher average ITGDI. Perhaps, the present study includes relatively more technology intensive industries and companies. Lastly, the study by Joshi et al. is from 2013 with the analysis being based on annual reports from 2008. The reports underlying the analysis of the present study are from 2015 . Therefore, the financial crisis and the regulatory changes it brought about, as well as the considerable progress in IT and its increasing relevance over those seven years might result in the higher average disclosure of three items. This argument links to the suggestions for future research:

Firstly, future research might also investigate the level of IT governance disclosure over time. As mentioned by Joshi et al. (2013): 'IT governance in a firm is not stationary' and factors such as the adoption of IT governance frameworks and implementation of new laws related to disclosure might take some time until they affect IT governance disclosure. Secondly, the regulatory environment at a general country level is not effective in raising the level of IT governance disclosure. Therefore, future research may focus on more specific disclosure alterations and on the introduction of new laws to study their effect on the level of IT governance disclosure. Here, future laws and acts, potentially in the banking sector, that make some IT governance disclosure aspects mandatory, are of particular interest. Event studies might then observe such new implementations' effect on IT governance disclosure and the resulting effects on corporate performance.

\section{Conclusion}

This research focuses on how the legal disclosure environment of a country and the industry IT strategic role affect the level of IT governance disclosure by companies. The statistical analysis finds no evidence for a relation between the legal disclosure environment, which is approximated by the Business Extent of

\footnotetext{
${ }^{27}$ A small subset of the sample was sent to other students from the fields of business and economics to detect and correct any rating biases by the researcher.
} 
Disclosure Index, and the level of IT governance disclosure. However, the industry IT strategic role does have a significant effect on the level of IT governance disclosure in this study. Thus, the study validates results of previous research across a broad set of countries and companies. Finally, there is no indication of any moderating effect between the legal disclosure environment and the IT strategic role.

\section{References}

Amir, E., \& Lev, B. (1996). Value-relevance of nonfinancial information: The wireless communications industry. Journal of accounting and economics, 22(1), 3-30. DOI: 10.1016/S01654101(96)00430-2

Anderson, M., Banker, R. D., \& Hu, N. (2003). The Impact of Information Technology Spending on Future Performance. Paper presented at the Proceedings of the International Conference on Information Systems. Seattle, USA December 2003. Association for Information Systems

ASX Corporate Governance Council. (2003). Principles of Good Corporate Governance and Best Practice Recommendations. Retrieved 24 April 2017 from http://www.ecgi.org/codes/documents/asx recommendations.pdf

Baek, H., Johnson, D., \& Kim, J. (2009). Managerial ownership, corporate governance, and voluntary disclosure. Journal of Business \& Economic Studies, 15(2), 44-61.

Bhojraj, S., \& Sengupta, P. (2003). Effect of corporate governance on bond ratings and yields: The role of institutional investors and outside directors. The Journal of Business, 76(3), 455-475.

Bollen, L., Joshi, A., \& Hassink, H. (2013). An empirical assessment of IT governance transparency: evidence from commercial banking. Information Systems Management, 30(2), 116-136. DOI: $10.1080 / 10580530.2013 .773805$

Brewster, C., Goergen, M., \& Wood, G. (2012). Varieties of capitalism and investments in human capital. Wilkinson Industrial Relations: A Journal of Economy and Society, 51(1), 501-527.

Chatterjee, D., Richardson, V. J., \& Zmud, R. W. (2001). Examining the shareholder wealth effects of announcements of newly created CIO positions. Mis Quarterly, 43-70.

Chau, G. K., \& Gray, S. J. (2002). Ownership structure and corporate voluntary disclosure in Hong Kong and Singapore. The International Journal of Accounting, 37(2), 247265.

Coombes, P. (2004). Living With Scrutiny. The McKinsey Quarterly 2004(2).

Dehning, B., Richardson, V. J., \& Zmud, R. W. (2003). The value relevance of announcements of transformational information technology investments. MIS Quarterly, 27(4), 637-656.

De Haes, S., Huygh, T., \& Joshi A. (2017). Exploring the Contemporary State of Information Technology Governance Transparency in Belgian Firms. Information Systems Management, 34(1), 20-37. DOI: $10.1080 / 10580530.2017 .1254444$

De Haes, S., \& Van Grembergen, W. (2009). An exploratory study into IT governance implementations and its impact on business/IT alignment. Information Systems Management, 26(2), 123-137. DOI: $10.1080 / 10580530902794786$

Dhaliwal, D. S., Li, O. Z., Tsang, A., \& Yang, Y. G. (2011). Voluntary nonfinancial disclosure and the cost of equity capital: The initiation of corporate social responsibility reporting. The accounting review, 86(1), 59-100. DOI: 10.2308/accr.00000005

Eng, L. L., \& Mak, Y. T. (2003). Corporate governance and voluntary disclosure. Journal of Accounting and Public Policy, 22(4), 325-345.

European Corporate Governance Institute. (n. d). Index of codes. Retrieved 26 April 2017 from http://www.ecgi.org/codes/all_codes.php

Florackis, C., (2005). Internal corporate governance mechanisms and corporate performance: evidence for UK firms. Applied Financial Economics Letters, 1(4), 211-216. DOI: 10.1080/17446540500143897

Gillan, S. (2006). Recent developments in corporate governance: An overview. Journal of Corporate Finance, 12(3), 381-402.

Gompers, P., Ishii, J., \& Metrick, A. (2003). Corporate governance and equity prices. The quarterly journal of economics, 118(1), 107-156.

88 Research

Papers 
Gordon, L. A., Loeb, M. P., Lucyshyn, W., \& Sohail, T. (2006). The impact of the Sarbanes-Oxley Act on the corporate disclosures of information security activities. Journal of Accounting and Public Policy, 25(5), 503-530.

Haniffa R. M., Cooke T. E. (2002). Culture, corporate governance and disclosure in Malaysian Corporations. Abacus, 38 (3), 317-349.

Hazarika, S., Karpoff, J. M., \& Nahata, R. (2012). Internal corporate governance, CEO turnover, and earnings management. Journal of Financial Economics, 104(1), 44-69.

Hinz, D. J. (2005). High Severity Information Technology Risks in Finance. $38^{\text {th }}$ Hawaii International Conference on System Sciences.

Hodne, N., Murphy, S., Ottenbacher, M., \& Ruggles, T. (2013). Australia and the United States: A Comparison and Contrast of Corporate Governance Practices. Drake Management Review, 3(1), 58-80.

IT Governance Institute (2003). Board Briefing on IT Governance. IT Governance Institute, $2^{\text {nd }}$ Edition. Retrieved 26 April 2017 from https://www.isaca.org/restricted/Documents/26904 Board Briefing final.pdf

Johannsen, W., \& Goeken, M. (2006). IT-Governance - neue Aufgaben des IT-Managements. [IT Governance - new tasks of IT Management]. HMD-Praxis der Wirtschaftsinformatik, 43, 250, 720.

Joshi, A., Bollen, L., Hassink, H., De Haes, S., \& Van Grembergen, W. (2013). Explaining IT Governance Disclosure through the Constructs of IT Governance Maturity and IT Strategic Role. Working paper. Maastricht University. Netherlands

Klapper, L. F., \& Love, I. (2004). Corporate governance, investor protection, and performance in emerging markets. Journal of corporate Finance, 10(5), 703-728.

Kusumawati, D. N. (2007). Profitability and corporate governance disclosure: An Indonesian study. Jurnal Riset Akuntansi Indonesia, 10(2), 131-46

La Porta, R., Lopez-de-Silanes, F., Shleifer, A., \& Vishny, R. W. (2000). Investor Protection and Corporate Goverance. Journal of Financial Economics, 58(1-2), 3-27.

La Porta, R., Lopez-de-Silanes, F., Shleifer, A., \& Vishny, R. W. (1997). Legal Determinants of External Finance. Journal of Finance, 52(3), 1131-1150

Maxwell, J., (2013). Qualitative Research Design. SAGE Publications, Inc. ISBN: 978-1-4129-8119-4

McKinsey and Company. (2002). Global Investor Opinion Survey: Key Findings. Retrieved 24 April 2017 from http://www.eiod.org/uploads/Publications/Pdf/II-Rp-4-1.pdf

Momot, T., Vashchenko, O., Avanesova, N., \& Chudopal, A. (2015). Corporate Governance Intelligence: Minority Shareholder's Aspects (Evidence from Ukraine). Chinese Business Review, 14(4), 210218. DOI: $10.17265 / 1537-1506 / 2015.04 .005$

OECD. (2004). OECD principles of corporate governance. Retrieved 24 April 2017 from https://www.oecd.org/corporate/ca/corporategovernanceprinciples/31557724.pdf

Raghupathi, W., (2007). Corporate governance of IT: a framework for development. Communications of the ACM. 50(8), 94-99.

Rouf, D., \& Abdur, M. (2011). Corporate characteristics, governance attributes and the extent of voluntary disclosure in Bangladesh. African Journal of Business Management. 5(19), 7836-7845.

Shroff, N., Sun, A. X., White, H. D., \& Zhang, W. (2013). Voluntary disclosure and information asymmetry: Evidence from the 2005 securities offering reform. Journal of Accounting Research. 51(5), 1299-1345.

Soh, C. S., (1996). Factors Influencing Company Information Disclosure: An Empirical Study of Companies Listed on the KLSE. Unpublished PhD. Thesis, University of Warwick, UK

Webb, P., Pollard, C., \& Ridley, G. (2006, January). Attempting to define IT governance: Wisdom or folly? Paper presented at the 39th Hawaii International Conference on System Sciences, Kauai, Hawaii.

Weill, P., \& Ross, J. (2004). IT governance: How top performers manage IT decision rights for superior results. Boston, MA: Harvard Business Press.

World Bank, Doing Business project (2017). Business extent of disclosure index. Retrieved 15 June 2017 from http://data.worldbank.org/indicator/IC.BUS.DISC.XQ

Zmud, R. W., Shaft, T., Zheng, W., \& Croes, H. (2010). Systematic Differences in Firm's Information Technology Signaling: Implications for Research Design. Journal of the Association for Information Systems. 11(3), 149-181.

Zuboff, S. (1988). In the age of the smart machine: Basic Book, New York 